4. Воробьев Е. М., Мишкина О. С. Протекционизм в условиях современного финансового кризиса // Вісник Харківського національного університету імені В.Н. Каразіна. - 2010. - №892. - C. 62-64.

5. Історія економічних вчень: Хрестоматія / За ред.. В.Е. Базилевича. - К.: Знання, 2011, с. 114-130.

6. Кулишер И. М. Основные вопросы международной торговой политики / И. М. Кулишер. - Челябинск: Социум, 2012. - 479 с.

7. Смит А. Исследование о природе и причинах багатства народов: перев.. с англ.. / А. Смит. - М.: ЭКСМО, 2007. - 648c.

8. Жид Ш. История экономических учений: перев.. с франц./ Ш. Жид, Ш. Рист. М.: Экономика, 1995. - 544 с.

9. Минкова К. В. Международная многосторонняя торговля: от античности до ВТО / К. В. Минкова. - СПб.: Изд-во СПб ун-та, 2006. -312 c.

10. Хасбулатов Р. И. Мировая экономика: В 2-х тт. - Т. ІІ / Р. И. Хасбулатов. М. Экономика, 2001. - 674 с.

11. Мэхэн А. Т. Влияние морской силы на Французскую революцию и Империю. 1802-1812: В 2-х т.т.: перев. с англ. - T. II / А. Т. Мэхэн. - М.: ООО АСТ, СПб.: Turra Fantastica, 2007. - 603 c.

12. Всемирная история: В 24-х тт. Т.16 Европа под влиянием Франции / А.Н.
Бадак, Н. М. Войнич и др. - М.: Литература, 1997. $-540 \mathrm{c}$.

13. Тимошина Т. М. Экономическая история зарубежных стран: учебн. пос. /Т. М. Тимошина. - М.: Изд. «Юстицинформ», 2000. $-496 \mathrm{c}$.

14. Маршалл A. Принципы экономической науки: В 3-х тт.: перев. с англ. - Т. 2 / А. Маршалл. - М.: Прогресс, 1993. $310 \mathrm{c}$.

15. Рикардо Д. Сочинения: В 5-ти тт.: перев. с англ. - Т. I / Д. Рикардо. - М.: Политиздат, 1955. -360 с.

16. Блауг М. Экономическая мысль в ретроспективе: перев. с англ. / М. Блауг. - М.: Дело ЛТД, 1994. - 383 с.

17. Кривуц Ю. Н. Дж. С. Милль о границах вмешательства государства в хозяйственную жизнь при системе laizzer faire //Вісник Харьківського національного університету імені В.Н. Каразіна. - №1144. Сер. «Міжнародні відносини. Економіка. Країзнавство. Туризм». - Т. 1. Економічні науки. - Вип. 3. - 2014. - С. 104-109.

18. Кривуц Ю. Н. Дж. С. Милль и его теория интернациональных стоимостей, или международной ценности / /Вісник Харьківського національного університету імені В.Н. Каразіна. - №1144. - Сер. «Міжнародні відносини. Економіка. Країзнавство. Туризм». - Т. 1. Економічні науки. - Вип. 3. - 2014. - С. 30-35.

Рецензент д.э.н., профессор ХНАУ им.В.Н. Каразина Воробьев Е.М. Эксперт редакционной коллегии д. э.н., профессор УкрГУЖТ Компаниеи В.В.

УДК 330.34.01(477)

\title{
ТЕОРЕТИЧНА СУТНІСТЬ КРИЗОВИХ ЯВИЩ В РОЗВИТКУ ЕКОНОМІЧНИХ СИСТЕМ
}

\author{
Маковоз О.В., к.е.н., доцент, \\ Жарко О.О., студент (УкрДУЗТ)
}

У статті наведено основні аспекти теоретичної сутності кризи в економічних системах. Доведено, щзо для здійснення оцінки економіки крайни за комплексом економічних $i$ фінансових показників треба в першу чергу визначити загальний стан системи, що $\epsilon$ важливим у процесі здійснення макроекономічного прогнозування. Також у статті доведено, 
що криза це переламний момент у розвитку будь якої економічної системи. В такій ситуаиіі готовність суспільства до перебудови і відповідна регуляторна політика уряду є запорукою успішного виходу «системи» з кризи на попередній рівень розвитку $i$, навіть, підйому на більш високу якісну сходинку в економічному зростанні.

Ключові слова: криза, економічна система,кризове явище, антикризове регулювання.

\title{
ТЕОРЕТИЧЕСКАЯ СУЩНОСТЬ КРИЗИСНЫХ ЯВЛЕНИЙ В РАЗВИТИЯ ЭКОНОМИЧЕСКИХ СИСТЕМ
}

\author{
Маковоз Е.В., к.э.н., доцент, \\ Жарко А.А., студент (УкрГУЖТ)
}

В статье приведены основные аспекты теоретической сущности кризиса в экономических системах. Доказано, что для оценки экономики страны по комплексу экономических и финансовых показателей надо в первую очередь определить общее состояние системы, является важным в процессе осуществления макроэкономического прогнозирования. Также в статье доказано, что кризис это переломный момент в развитии любой экономической системы. В такой ситуации готовность общества $\kappa$ перестройке $u$ соответствующая регуляторная политика правительства является залогом успешного выхода «системыл" из кризиса на предылущий уровень развития и даже подъема на более высокую качественную ступень в экономическом росте.

Ключевые слова: кризис, экономическая система, кризисное явление, антикризисное регулирование.

\section{THE THEORETICAL ESSENCE OF THE CRISIS PHENOMENA IN THE DEVELOPMENT OF ECONOMIC SYSTEMS}

\author{
Makovoz O. V., candidate of Economics, associate Professor, \\ Zharko O. O., student (USURT)
}

The crisis of the modern market economy arose due to the formation of the world economy at the turn of the century because of the growing socialization of production in a national and international scale. The events that take place in the economy of Ukraine is closely connected with the General course of development of the world economy. Modernity has put before the governments of most countries of the world, including Ukrainian, the need for urgent action to prevent the devastating impact of the global financial crisis on the economy of the country. The unprecedented scale of transitivity and complexity of the forms of the crisis give grounds to speak about the new quality of these phenomena in the global economy. The depth and length of transformational recession, obviously, depend on the extent of the established imbalances: the volume of the transformational challenges from the point of view of art and technology; the degree of development of the real market relations, and the like. The problem is in particular the determination of the need for effective crisis management in transitional processes, the adoption of adequate solutions that should be taken in accordance with the emerging requirements and identifying the theoretical and methodological utmost crisis phenomena in the development of economic systems.

Keywords: crisis, economic system,crisis phenomenon, crisis management.

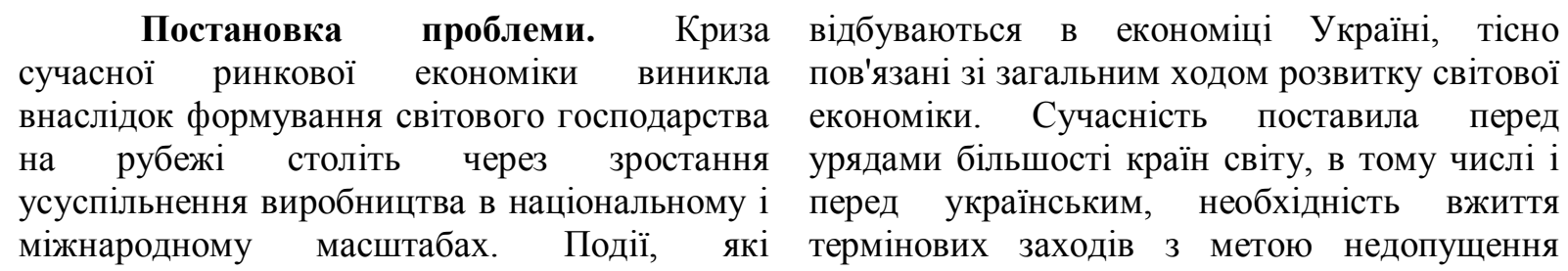

Вісник економіки транспорту і промисловості № 53, 2016 
руйнівного впливу світової фінансової кризи та політичних негараздів на економіку країни. Небачений раніше масштаб перехідності і складність форм кризових явищ дають підстави говорити про нову якість цих явищ у світовій економіці. Глибина і тривалість трансформаційного спаду, очевидно, залежать від ступеня встановлених диспропорцій: об'єму трансформаційних завдань 3 точки зору рівня техніки i технологій; ступеня розвитку реальних ринкових відносин, тощо. Проблема полягає в особливому підході до теоретичного визначення поняття «криза» 3 метою визначення першочергових необхідних адекватних рішень, які треба приймати відповідно до посталих потреб та визначенні теоретико-методологічної сутності кризових явищ в розвитку економічних систем.

\section{Аналіз досліджень і публікацій.}

В економічній літературі проблеми теоретичних аспектів визначення поняття «кризове явище» або «криза» в останні роки розглянуті в наукових працях як закордонних, так і вітчизняних економістів досить широко. Значною мірою це обумовлено важливістю розвитку даної проблематики для стабільного розвитку економіки. Вагомий внесок у пізнанні теорії економічних криз вносять дослідження, присвячені різним аспектам економічних криз в контексті економічного розвитку, таких учених, як О.Г. Білорус [1], Б. I. Кабаця [2], Т.П. Вахненко [3] та інших. Присвячені вивченню теоретичних та практичних засад вивчення кризових явищ та антикризового регулювання та управління, праці також таких вчених, як: О.О. Терещенко [4], С.В. Мочерний [5], В.Г. Воронкова [6], С.Н.Горлов-Марченко [7], О. О. Костенко Попова [8], В.Л. Диканя, І.В. Воловельської [9] та багатьох інших. В їх роботах розглянуто коло проблем, пов'язаних 3 ідентифікацією кризових процесів, визначення причин та наслідків криз, вивченням механізму антикризового управління як на макро-, так і на макрорівні. Треба відмітити, що таким питанням присвячені також роботи закордонних відомих вчених, таких як: С. Массон [10], Р. Буссе [11] та багатьох інших.

Разом 3 тим, незважаючи на численні дослідження різних аспектів визначення понять кризи та кризового явища, у науці не склався цілісний підхід до комплексної системи бачення цього поняття. Сьогодні немає конкретного повноцінного інструментарію для здійснення у процесі макроекономічного прогнозування оцінки стану економічної системи в контексті визначення ступеня прояву кризових явищ, метою даної статті $є$ розроблення підходу до визначення теоретичної сутності та формування наукового концепту «криза» у контексті економічної системи.

\section{Основний матеріал.}

Загальновідомо, що період часу між двома найвищими точками розвитку економіки, після яких починається рецесія, прийнято називати економічним циклом, який, незважаючи на його тривалість (цикл Кітчина, Жюглара чи Кондратьєва), має однакову структуру і складається з чотирьох фаз: піку буму, рецесії (спаду), дна та пожвавлення (піднесення) [4,5]. Основною метою урядів усіх країн в процесі розробки прогнозів і перспективних планів розвитку на довгостроковий період $\epsilon$ Згладжування економічних циклів, подовження перебування економіки країни у фазі піднесення та скорочення фази рецесії. Зазначимо, що при наявності єдиної думки щодо переліку i послідовності фаз економічного циклу, жоден iз науковців не дає конкретного визначення кризи як частини економічного циклу, тобто не вказує, 3 якого моменту рецесія перетворюється на кризу i, відповідно, коли можна казати про закінчення кризи. Також спостерігається багатоваріантність у застосуванні економічних i фінансових показників науковцями i практиками для підкріплення думки про «кризовість» стану економічної системи.

Важливим моментом у дослідженні питання циклічності в процесі розробки прогнозів макроекономічного розвитку $\epsilon$ також визнання факту об'єктивності настання кризи, що дозволяє сформулювати висновок про кризу як переламний момент у розвитку економічної системи. В такій ситуації готовність суспільства до перебудови i відповідна регуляторна політика уряду $\epsilon$ запорукою успішного виходу країни із кризи на попередній рівень розвитку i, навіть, підйому на більш високу якісну сходинку в економічному зростанні.

Таким чином, необхідність успішного вирішення подібного завдання та відсутність 
єдиного підходу до визначення самого поняття «економічна криза» в працях як вітчизняних, так i зарубіжних авторів, обумовлюють актуальність проблеми розроблення підходів до визначення наукового концепту «економічна криза» у термінології циклічного розвитку, створюють необхідність розробки системи оціночних показників-індикаторів для визначення фази економічного циклу в процесі макроекономічного прогнозування 3 точки зору отримання уяви про наближення економічної системи до піку (буму), за яким об'єктивно має настати фаза рецесії, кризи тощо. Для цього, на наш погляд, має бути розроблена система оціночних показників інтегрованих у подальшому в систему загальнодержавного управління.

Тому, розглянемо основні роботи вчених 3 цих питань. Вахненко Т.П., розглядаючи фактори i механізми дії фінансової кризи в Україні [3,с.3], у якості їі «сигнальних» індикаторів аналізує такі показники, як розмір зовнішнього боргу країни та його співвідношення із наявними міжнародними резервами країни, рівень і «справедливість» курсу національної валюти, темпи кредитування споживчих витрат вітчизняної економіки, зміни цін на реальні активи та цінні папери вітчизняних емітентів.

Білорус О. [1, с.4], характеризуючи прояв кризових явищ в українській економіці, акцентує увагу на таких показниках, як вартість акцій вітчизняних компаній, фінансовий стан банківських установ, рівень безробіття, падіння обсягів будівництва та виробництва, пов'язані із зупиненням роботи підприємств. Важливим чинником впливу на стан економіки він також зазначає розмір зовнішнього боргу iі корпоративного та приватного секторів.

Досягнення такої мети передбачає вирішення завдання визначення переліку характеристик економічної системи та формування критеріїв їх оцінки, які при розробці прогнозів і складанні планів макроекономічного розвитку нададуть можливість стверджувати про близьке настання кризи, а також розробка методологічного підходу до формування системи індикаторів, що дають можливість визначити (спрогнозувати) час їі початку.

Сучасна наука активно користується терміном «криза»у різних інтерпретаціях. Мова йде про «загальноекономічну кризу», «економічну кризу», «фінансову кризу», зустрічаються поняття «криза платіжного балансу», «криза перевиробництва» та «макроекономічна криза».

Іншомовні джерела також пропонують різноманітність у застосуванні терміну «економічна криза». Для цього застосовуються терміни Economic crisis, Growth recession, Recession i т.i. В той же час, користуючись зазначеними поняттями, автори не дають власного конкретного визначення терміну «криза» $[11,12,13]$

На думку Мочерного С.В.: «Криза (від грецької krisis - поворотний пункт) - основна фаза періодичного економічного циклу, різке погіршення економічного становища в країні. Основними формами прояву кризи є значний спад виробництва, масові банкрутства підприємств (в тому числі банків), значне зростання безробіття, фінансово-кредитна криза, падіння цін, зростання відсоткової ставки та інше» $[5$, с.215].

На думку В.Г. Воронкової, під кризою «розуміють специфічну фазу розвитку, яка характеризується різкою зміною звичного устрою життя системи, порушенням іiі рівноваги» [6, с.84].

Горлов-Марченко С.Н. у своїй монографії «Кризи» характеризує кризову ситуацію як «максимально можливу ступінь зміни і відхилень від нормальної ситуації, що призводить до негативних впливів на систему або до негативного результату». При цьому під нормальною ситуацією він розуміє «максимально можливу ступінь змін і відхилень ситуації від цілей, завдань і інтересів держави, що не призводить до негативних наслідків або результатів» [7, с. 96].

Наслідками кризових ситуацій не завжди є негативні зміни та результати. До того ж, у визначення закладена позиція звуження «нормальної ситуації» до відповідності ходу розгортання процесу державним цілям розвитку. Насправді ж кризові процеси можуть мати місце при повній відповідності стану системи державним планам, адже державні завдання та інтереси не можуть бути охарактеризовані як такі, що претендують на звання абсолютної істини. 
На основі вивчення існуючих теоретичних підвалин і аналітичних джерел, визначимо, що криза - це такий стан системи, а якого відбувається динамічна безповоротна трансформація іiі елементів, втрата звичних зв'язків та порушення збалансованості системи. Під економічною кризою розуміємо таке порушення економічних зв'язків та пропорцій, за якого неможливе подальше існування соціальної системи у попередньому вигляді. Тобто, по суті, це руйнація внутрішньої стійкості економічної системи.

Економічна криза, таким чином, $\epsilon$ найбільш загальним поняттям, яке містить у собі ознаки присутності у більшій чи меншій мірі всіх типів криз: грошово-кредитної, валютної, фінансової тощо. Виходячи з цього, на наближення економічної системи до кризи має вказувати аналіз комплексної системи показників, що мають характеризувати стан економіки країни, фінансів, грошовокредитних відносин, валютного ринку, а також відображати зв'язки, існуючі між певними інституціями економічної системи.

В контексті вищевказаних міркувань пропонується визначення поняття економічної кризи, як періоду, що триває від точки зміни фази підйому економічного циклу на фазу рецесії (точки буму або піку), протягом якого стан економічної системи характеризується перевагою тенденції до спаду (рецесії) економіки над тенденцією до іï пожвавлення, до періоду досягнення економікою «дна», коли тенденції до спаду переконливо змінюються тенденціями до пожвавлення.

\section{Висновки.}

Таким чином, початок кризи визначається точкою піку в економічному циклі, а кінець - точкою дна. Напрямок розвитку економічної системи у бік початку чи закінчення кризи визначається переважаючими тенденціями до спаду чи пожвавлення економічного розвитку. Деякі фахівці-практики при наближенні економіки до фази буму, що відповідно до запропонованого нами визначення $\epsilon$ початком економічної кризи, застосовують саме термін «перегрівання економіки», що свідчить саме про надмірний вплив пожвавлюючих чинників на розвиток економічної системи.

Комплексність і складність поняття «економічна криза» мушують до здійснення оціночних дій за багатьма аспектами становища економічної і фінансової системи для визначення реального стану економіки, що досліджується в контексті визначення ступеня прояву кризових явищ у іiі реальному i фінансовому секторах.

\section{СПИСОК ЛІТЕРАТУРИ}

1. Білорус О.Г. Сучасна світова фінансово-економічна криза як прояв тотальної кризи системи глобалізму /O. Білорус // Економічний часопис - XXI. - 2008. - № 11 - 12. - С. 3 - 7 .

2. Кабаця Б.І. Еволюція теоретичних поглядів на джерела та можливості державного регулювання динаміки економічного зростання / Б.I. Кабаця // Науковий вісник: збірник науково-технічних праць. - Л. : НЛТУУ. - 2007. - Вип. 17.3. - С. 189-202.

3. Вахненко Т.П. Фінансова криза в Україні: фактори, механізми дії, заходи подолання / Т.П. Вахненко // Фінанси України. -2008 . - № 10. - C. 3 - 21 .

4. Терещенко О.О. Антикризове фінансове управління на підприємстві/ O.O. Терещенко// монографія . - К.: КНЕУ, 2004. $-268 \mathrm{c}$.

5. Мочерний С.В. Основи економічний знань / С.В. Мочерний // Підручник - - К.: Видавничий центр «Академія», 2009. - 304 с.

6. Воронкова В.Г. Соціальноекономічне прогнозування / В.Г. Воронкова // навчальний посібник . - К.: ВД «Професіонал», 2004. - 283 с.

7. Горлов-Марченко С.Н. Кризисы. Выход: кадры, управление, экономикс / С.Н. Горлов - Марченко . - Кировоград: ПолимедСервис, 2000. - 370 c.

8. Костенко-Попова О. Кризис боится солнца. Как нам использовать испанский опыт / О. Костенко-Попова // Аргументы и факты. 2009. - № 26 // [Электронный ресурс]. Режим доступа: http://www.aif.ru/ money/article/27641.

19. Дикань В.Л. Економічна безпека підприємства: навчальний посібник. / В.Л. Дикань, І.В. Воловельська, О.В. Маковоз. Х.:УкрДАЗТ, 2011. - 270 с.

10. Mason Edward S. The economic and social modernization of the regions. Harvard University Press, 1999. - 422 p. 
11. Буссе Ральф. Обзор антикризисных налоговых мер в Европе // Антикризисные или конъюнктурные пакеты : материалы II Международного научно-практического симпозиума по актуальным проблемам налоговой политики // Вестник палаты налоговых консультантов. - 2009. - № 5-6 // [Электронный ресурс]. - Режим доступа : http://www.palata-

nk.ru/php/content.php?id=1726.
12. Досвід країн світу щодо подолання наслідків світової фінансової кризи [Електронний ресурс]. - Режим доступу: // http://www.me.gov.ua/file/link/

146035/file/krisis_p.doc

13. Економічна криза в Україні: виміри, ризики, перспективи [Електронний ресурс] - Режим доступу до ресурсу: http://www.niss.gov.ua/book/vidannya/Ekon.kriz a.pdf.

Рецензент д.е.н., професор УкрДУЗТ Зайцева І.Ю. Експерт редакційної колегії к.е.н., доцент УкрДУЗТ Токмакова І.В.

УДК 339.727

\title{
АНАЛІЗ СУЧАСНИХ ТЕНДЕНЦІЙ РОЗВИТКУ МІЖНАРОДНОГО ФОНДОВОГО РИНКУ
}

\author{
Савін Р.С., аспірант (ХНУ ім. В.Н.Каразіна)
}

\begin{abstract}
В роботі проаналізовані тендениії сучасного етапу розвитку міжнародного фондового ринк в інформаційній економіці. Суттєве місие відводиться позииіюванню міжнародного фондового ринку в глобальній фінансовій архітектурі та тій ролі, яку відіграють транскордонні потоки капіталів в формуванні його ключової тенденції. Показані процеси трансформаиії інституціональної структури міжнародного фондового ринку та роль та значимість міжнародних фінансових центрів в процесі глобалізащії. Визначені подальші шляхи розвитку фондового ринку Украӥни для інтеграції у світове господарство
\end{abstract}

Ключові слова : глобалізація, міжнародний фондовий ринок, міжснародні фінансові центри, інтернаціоналізація, інформаційні технології, цінні папери.

\section{АНАЛИЗ СОВРЕМЕННЫХ ТЕНДЕНЦИЙ РАЗВИТИЯ МЕЖДУНАРОДНОГО ФОНДОВОГО РЫНКА}

\author{
Савин Р.С., аспирант (ХНУ им. В.Н.Каразина)
}

В работе проанализированы тенденции современного этапа развития международного фондового рынка в информационной экономики. Существенное место авторами отводится позищионированию международного фондового рынка в глобальной финансовой архитектуре и той роли, которую играют трансграничные потоки капиталов в формировании ключевой тенденции. Показаны прочессы трансформации институциональной структуры международного фондового рынка и значения международных финансовых иеетров в эпоху глобализации.Определені дальнейшие чаги развития фондового рынка Украины для интеграчии в мировое хазяйство.

Ключевые слова : глобализация, международный фондовый рынок, международные финансовые центры, интернационализация, информационные технологии, ценные бумаги. 